\title{
COMPANIES MERGER - AN IMPORTANT FACT OF REORgANISATION
}

\author{
HORJA, I. M. \& VANCEA, S.
}

Abstract: The current conditions in the Romanian economy needs to find answers to problems such as increasing variety of companies participating in economic life on the one hand and managers on the other. To be able to adapt to these permanent changes, Romanian entities must be sufficiently flexible and innovative in order to maintain the products and services, to provide maximum quality for the customer and not least in order to meet deadlines and to maintain the market. The aim and the objective of the study is to identify and clarify major theoretical issues related to restructuring strategies, identify the main ways of restructuring in order to develop or removal from the market of bad companies, as well as an analysis of the evolution of these restructuring operations nationally and internationally.

Key words: strategy, merger, reorganization
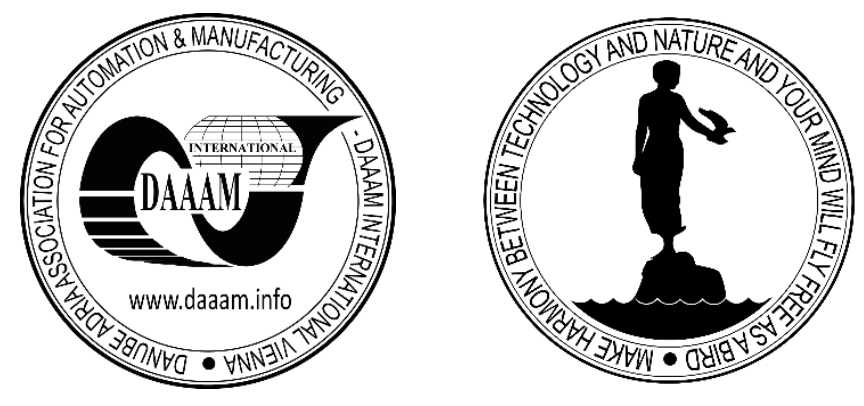

Authors' data: Associate. Prof. Horja, I[oana] M[onica]*; Lecturesr Phd. Vancea, S[maranda]**, *University Dimitrie Cantemir, Bodoni Sandor 3-5, Targu Mures, Romania, ** University Dimitrie Cantemir, Bodoni Sandor 3-5, Targu Mures, Romania, moni_horja@yahoo.com, smarandavancea@yahoo.com

This Publication has to be referred as: Horja, I[oana] M[onica] \& Vancea, S[maranda] (2016). Companies Merger - an Important Fact of Reorganization, Chapter 29 in DAAAM International Scientific Book 2016, pp.325-334, B. Katalinic (Ed.), Published by DAAAM International, ISBN 978-3-902734-09-9, ISSN 1726-9687, Vienna, Austria

DOI: $10.2507 /$ daaam.scibook.2016.29 


\section{Introduction}

Defined as a set of actions of reorganization and renewal of the economy at all levels, guided by the criterion of performance, efficiency and social welfare, merger \& acquisitions are processes which are intended to ensure the creation of new structures, to generate changes in the structure of ownership in various ways. Economical reorganization and social development are two inseparable steps of economic reality. At enterprise level, reorganization and development can have different ways.

The companies, as legal persons can be formed, can be consolidated or developed, or reduce their activity or can be dissolved or liquidated function of the economic conjuncture favourable or not. If development and consolidation, and reducing the activity maintain the legal person, dissolution and liquidation goes to the erasure of the company from the economic life.

In the Romanian economic environment change has become normality, but the pace of change has accelerated, Romanian companies are faced with a number of increasingly larger competitors, many of them coming from outside the country. To be able to adapt to these changes permanent, Romanian companies must be sufficiently flexible and innovative in order to maintain the products and services to provide maximum quality for the customer and not least in order to meet deadlines and to maintain the market.

\section{Merger - a way of reorganization}

The processes of reorganization are ways that managers must know and use them to resist to the competitive environment. There is not a pattern, a standard for these ways of reorganization, each entity has its characteristics, each entity is faced with different situations depending on who must take certain decisions. Reorganization is not a routine or cannot take place according to algorithms. There is a certain procedure to include a number of steps and produce a new mechanical process.

In Romania merger was used for state capital company's reorganization.

Before 1990, Romanian economy had a high rate of concentration by administrative bases. For passing to a transitory economy were necessary two steps:

- economy transformation by divisions of big companies

- economical, commercial and financial grouping of companies through merger.

A strategically develop of an enterprise imposes frequently the revise of the organization, either internal measures or profound measures which affects the company structure. These development ways are part of the strategy which was chose by the company management for increase the competitive advantage for obtaining bigger benefits. One of these ways of development is merger.

The merger of a company is determined by the influential of many facts, such as [Horja, I.M.; et.al. (2010). Operaţiunile de restructurare a societăţilor comerciale, Risoprint Publishing House, Cluj Napoca]: 
- economic concentration - the situation when a few economic agents have a high percent of economic activity on a specific market (such as total sales, assets or working capital). Merger is one of the economic concentration forms

- economic development in many countries, market globalization - the firs step to the appearance of powerful companies which dominated segments of market and the development of financial market makes easier the shares acquisition

- access to international market - as information, communication were diversified which become a simulative fact through companies development and entrance to international market.

The merger \& acquisition are similar to the process of economic development and economic growth, processes which are necessary process to majority of companies operating in the Romanian economy today.

This paper aims to analysis of the merger and acquisition processes as a part of companies reorganization, reorganization seen in terms of growth and development of companies. Thus, reorganization in terms of economic growth can be achieved through merger/absorbtion and acquisitions.

The main idea of merger and acquisition is one plus one makes three. The key principle behind buying a company is to create shareholder value over and above that of the sum of the two companies. Strong companies will act to buy other companies to create a more competitive, cost-efficient company. The companies will come together hoping to gain a greater market share or achieve greater efficiency. Because of these potential benefits, target companies will often agree to be purchased when they know they cannot survive alone.

When a company takes over another one and clearly becomes the new owner, the purchase is called an acquisition. From a legal point of view, the target company ceases to exist and the buyer "swallows" the business, and stock of the buyer continues to be traded.

In the pure sense of the term, a merger happens when two firms, often about the same size, agree to go forward as a new single company rather than remain separately owned and operated. This kind of action is more precisely referred to as a "merger of equals." Both companies' stocks are surrendered, and new company stock is issued in its place. [Reed, F. S. \& Lajoux, R. A. (2007). The Art of M\&A, 4th Ed. McGraw-Hill Professional Publishers, Australia]

From judicial point of view, merger is the operation whereby one or more companies are wound up without going into liquidation and transfer to another/ company that they set up all their assets and liabilities in exchange for the issue to the shareholders of the company or companies being acquired/merged of shares in the acquiring/new company and a cash payment, if any, not exceeding $10 \%$ of the nominal value of the shares so issued or, where they have no nominal value, of their accounting par value.

Many analysts consider the merger as an acquisition option. Merger, similar to acquisition by buying a package of major business, a change of ownership of shares by the shareholders to one of the merging companies will gain control of the company resulting from the merger. Although not necessarily a rule, the shareholders of 
companies subject to merger remain shareholders of the entity resulting from the merger while the shareholders of companies acquired (in the case of transactions of "cash") no longer remain in the structure of post-transaction. The line of demarcation between the merger and acquisition, however, is very "thin" in the so-called 'trade actions against shares ("share-for-share swaps"), transactions of "non-cash, shareholders of the company purchased shares changing which they hold shares of the acquiring company thus remaining shareholding structure post-transaction. [Bruner, R. (2011). Applied Merger \& Acquisition, ISBN 9781118160824, John Wiley \&Sons]

\section{Reasons of a merger}

Basically, the gain of efficiency is the main reason for the reorganization transactions when two companies merge, a company that manufactures a complementary range of products existence may complete this range contributing to the total demand of products. [Tiron, T. A. (2005). Business Combination-Mergers and Acquisitions, Accent Publishers, Bucharest]

1. Financial reasons - they haven't any theoretical commercial or industrial justification, but in practice it is difficult to make a complete dissociation of the commercial reasons for the financial reasons because behind the financial assets there is always an industrial reality and vice versa.

2. Special reasons - consisting of improving business management, personal reasons managers or shareholders.

3. Tax reasons - They may be the essence of reorganization operations due to the potential merger effective use of fiscal levers. By reorganization operations is possible to obtain economies of reducing taxes.

Merger is based on a few reasons such as:

- earning efficiency: when two or more company merged, an enterprise who makes a product who is complementary to the existing product can complete the products going to the growth of total demand. The economies which results by this way are obtained through synergy, the resulted company through fusion is more than summing the parts (scale economies). The economies are obtained through synergy; the new company obtained through merger is more advantageous than the first companies. Synergy is the magic force that allows for enhanced cost efficiencies of the new

business. Synergy takes the form of revenue enhancement and cost savings.

By merging, the companies hope to benefit from the following:

1. Staff reductions - As every employee knows, mergers tend to mean job losses. Consider all the money saved from reducing the number of staff members from accounting, marketing and other departments. Job cuts will also include the former CEO, who typically leaves with a compensation package.

2. Economies of scale - Yes, size matters. Whether it's purchasing stationery or a new corporate IT system, a bigger company placing the orders can save more on costs. Mergers also translate into improved purchasing power to buy equipment or office supplies - when placing larger orders, companies have a greater ability to negotiate prices with their suppliers. 
3. Acquiring new technology - To stay competitive, companies need to stay on top of technological developments and their business applications. By buying a smaller company with unique technologies, a large company can maintain or develop a competitive edge.

-improved market reach and industry visibility - Companies buy companies to reach new markets and grow revenues and earnings. A merge may expand two companies' marketing and distribution, giving them new sales opportunities. A merger can also improve a company's standing in the investment community: bigger firms often have an easier time raising capital than smaller ones.

That said, achieving synergy is easier said than done - it is not automatically realized once two companies merge. Sure, there ought to be economies of scale when two businesses are combined, but sometimes a merger does just the opposite. In many cases, one and one add up to less than two.

So, the synergies are supplementary benefits which can be obtained through business combination. Synergies have many forms: [Horja I.M. (2009). Companyes reorganization - an important fact in the current economy, The 6th International Conference on Management of Technological Changes, 3-5 september 2009, Alexandroupolis, Grecia]

1. sales synergies - the new company has all the distributions channels, promotions, common deposits;

2. operational synergies - a better using of facilities and human capital, a decrease of unit acquisition costs for raw materials;

The main purpose of merger is increasing the company value through new opportunities in a new business area for increase the competitively and economic performance.

3. investment synegies - using in common equipments, some activity, common stocks of raw materials

4. managerial synergies - a good management of the absorbent can increase the absorbed management

5. Financial synergies - obtaining economy in financial expenditures credits with little interests).

When the necessary founds for development aren't enough through merger this thing can be solved. The companies with more liquidity but with less possibility of investments can choose merger.

- the improvement of administration: some companies are administrated less efficient and by merging the rent ability can grow

- the effect of information: because of the reduced degree of information between the leaders ant the market, the growth of the value can appear when through a fusion new information are accessible

-the fiscal reasons: these can be the engine of the fusions because of the possibility of using more efficient the fiscal levers.

Through operations of reorganization can obtain economies from the decrease of the taxes. Operational and deductible fiscal losses of the absorbed company can be use by the absorbing company for decrease the taxes in case of merger. 
Horja, I. M. \& Vancea, S.: Companies Merger - an Important Fact of Reorganization

- activities diversification - is used as a way of risk reduction

- consolidation of share market - the absorbing company can decide to absorb one or more competitive companies or to merge with them

-vertical integration of company - the company adopts a strategy of integration by absorbing a main supplier or a main customer

- company surviving - a company with difficulties can be saved by another.

\section{Mathematic model of merger}

For knowing if a merger or division is good for the company a detailed analysis is necessary, a feasibility study. A feasibility study is a preliminary study undertaken to determine the merger's or division's viability. These results of this study are used to make a decision whether to proceed with the project, or table it. If it indeed leads to a project being approved, it will — before the real work of the proposed project starts be used to ascertain the likelihood of the project's success. It is an analysis of possible alternative solutions to a problem and a recommendation on the best alternative.

Merger and divisions are made for purpose of improving activity, they should be profitable. But can be situations in which merger or division fails. For avoiding these cases, there is a prealable time of merger and division, time when the companies must know each other. In this time there must be done a lot of studies and analyses by consulting companies such as commercial studies, assets evaluation, company evaluation, financial analyses, and audit. These studies are the base of decision of continuing merger or division or not.

Analyse must show the evolution of the company in the future. Before the decision of merger or division there are necessary:

- Financial - economic documentation - Any reorganization or development of a company supposes investments for a long period of time. These investments must be restructured on factors of production such as from there combination the economic effect should be maximum

- Technical - economic documentation - Technical analysis considers only the actual price behaviour of the market or instrument, based on the premise that price reflects all relevant factors before an investor becomes aware of them through other channels.

It, for example, can decide whether an order processing be carried out by a new system more efficiently than the previous one.[Sherman, A. (2011). Merger \& Acquisitions from A to Z, ISBN - 13 978-0-8144-1383-8, Amacom Div Mgmt Assn, New York]

The mathematic model of merger and the steps of a merger are: 


\begin{tabular}{|c|c|c|c|}
\hline Financial operations & $\begin{array}{l}\text { Absorbtive } \\
\text { A } 100 \%\end{array}$ & $\begin{array}{l}\text { Absorbed } \\
\text { B 100\% }\end{array}$ & Observations \\
\hline $\begin{array}{l}\text { - establishing the economic value } \\
\text { of the companies part to the } \\
\text { merger }\end{array}$ & $\mathrm{VANA}=\mathrm{AA}-\mathrm{LA}$ & $\begin{array}{l}\mathrm{VANB}=\mathrm{AB} \\
-\mathrm{LB}\end{array}$ & $\begin{array}{l}\text { VAN - net value } \\
\text { assets } \\
\text { A - total assets } \\
\text { L - total liabilities }\end{array}$ \\
\hline $\begin{array}{l}\text { - establishing the market value } \\
\text { per share of the companies }\end{array}$ & $\mathrm{MVA}=\mathrm{VANA} / \mathrm{NA}$ & $\begin{array}{l}\text { MVB } \\
=\text { VANB } / \mathrm{NB}\end{array}$ & $\begin{array}{l}\text { MV - market value } \\
\text { for shares } \\
\text { NA- number of } \\
\text { shares before } \\
\text { merger for A } \\
\text { NB- number of } \\
\text { shares before } \\
\text { merger for B }\end{array}$ \\
\hline - determination of exchange rate & \multicolumn{2}{|c|}{$\mathrm{R}=\mathrm{MVB} / \mathrm{MVA}$} & $\begin{array}{l}\mathrm{R} \text { - exchage rate } \\
\text { for shares }\end{array}$ \\
\hline $\begin{array}{l}\text { - calculation of the number of } \\
\text { shares issued by A }\end{array}$ & \multicolumn{2}{|c|}{$\mathrm{NI}=\mathrm{VANB} / \mathrm{MVA}$} & $\begin{array}{l}\mathrm{NI}-\text { number os } \\
\text { shares issued by A }\end{array}$ \\
\hline $\begin{array}{l}\text { - calculation of the capital } \\
\text { increase for A }\end{array}$ & \multicolumn{2}{|c|}{$\mathrm{CIA}=\mathrm{NI} * \mathrm{VNA}$} & $\begin{array}{l}\text { CIA - capital } \\
\text { increase at A } \\
\text { company } \\
\text { VNA - nominal } \\
\text { value of A shares }\end{array}$ \\
\hline - calculation of merger premium & \multicolumn{2}{|c|}{$\mathrm{PM}=\mathrm{VANB}-\mathrm{CIA}$} & $\begin{array}{l}\mathrm{PM} \text { - merger } \\
\text { premium }\end{array}$ \\
\hline
\end{tabular}

Tab.1 Mathematic model of merger.

Analyse must show the evolution of the company in the future. Before the decision of merger or division there are necessary: [Horja I.M.; et.al (2009). Merger \& Acquisition: Important Processes in Romania, The 20 th Symposium "Intelligent Manufacturing \& Automation: Focus on Theory, Practice and Education", 25-28, Vienna, Austria, ISBN 978-3-901509-70-4, Nov. 2009]

- financial - economic documentation - Any reorganization or development of a company supposes investments for a long period of time. These investments must be restructured on factors of production such as from there combination the economic effect should be maximum.

- technical - economic documentation - Technical analysis considers only the actual price behaviour of the market or instrument, based on the premise that price reflects all relevant factors before an investor becomes aware of them through other channels.

This documentation is realized in a few steps:

- opportunity study - for identification of reorganization possibilities, advantages or disadvantages, economic brands of companies, geographical area, the chances of the new company on the market

- prefeasibility study - for identification the market capacity, the human capital, financial prognosis, factors of production

- feasibility study - shows the necessity of reorganization and the economic and financial results which can be obtained in the future 
Horja, I. M. \& Vancea, S.: Companies Merger - an Important Fact of Reorganization

Companies in the small to middle market segment need to understand the key drivers of valuation in order to focus their operating goals to increase their value. [Andersen, H; Havila, V \& Nilsson, F. (2013). Merger \& Acquisitions: The Critical Role of Stakeholders, ISBN 978-0-415-53652-3, Routledge, New York]

\section{Study case - merger}

Companies $\mathrm{A}$ and $\mathrm{B}$ decide the operation of merger, $\mathrm{A}$ is the merging company and $\mathrm{B}$ is the merged company.

Step 1: The valuation of assets and liabilities

Results: no differences of valuation

Step 2: The financial statements before merger

\begin{tabular}{|c|c|}
\hline Element & Values (EUR) \\
\hline Buildings & 200.000 \\
\hline Noncurrent assets & 200.000 \\
\hline Inventories & 4.100 \\
\hline Debtors & 1.900 \\
\hline Cash & 3.000 \\
\hline Current assets & 9.000 \\
\hline Total assets & 209.000 \\
\hline Suppliers & 4.700 \\
\hline Current liabilities & 4.700 \\
\hline Long term borrowings & 80.000 \\
\hline Non current liabilities & 80.000 \\
\hline Share capital (100 shares) & 50.000 \\
\hline Reserves & 60.000 \\
\hline Retained earnings & 3.300 \\
\hline Profit & 11.000 \\
\hline Total equity & 124.300 \\
\hline
\end{tabular}

Tab.2 Financial statement - company A

\begin{tabular}{|c|c|}
\hline Element & Values (EUR) \\
\hline Machinery & 80.000 \\
\hline Noncurrent assets & 80.000 \\
\hline Inventories & 2.800 \\
\hline Cash & 2.900 \\
\hline Current assets & 5.700 \\
\hline Total assets & 85.700 \\
\hline Suppliers & 4.300 \\
\hline Current liabilities & 4.300 \\
\hline Long term borrowings & 52.400 \\
\hline Provisions & 1.000 \\
\hline Non current liabilities & 53.400 \\
\hline
\end{tabular}




\begin{tabular}{|c|c|}
\hline Share capital (2.000 shares) & 20.000 \\
\hline Reserves & 3.500 \\
\hline Profit & 4.500 \\
\hline Total equity & 28.000 \\
\hline
\end{tabular}

Tab.3 Financial statement - company B

Step 3: Calculation of value net assets

VNAA $=$ Total assets $\mathrm{A}-$ Total liabilities $\mathrm{A}=(200.000+9.000)-(4.700$

$+80.000)=124.300$

$\mathrm{VNAB}=$ Total assets $\mathrm{B}-$ Total liabilities $\mathrm{B}=(80.000+5.700)-(4.300$

$+52.400+1.000)=28.000$

Step 4: Calculation of market value per share

$\mathrm{MVA}=$ Value net assets $\mathrm{A} /$ Number of shares $\mathrm{A}=124.300 / 100=1.243$

$\mathrm{MVB}=$ Value net assets $\mathrm{B} / \mathrm{Number}$ of shares $\mathrm{B}=28.000 / 2.000=14$

Step 5: Calculation of exchange ratio

$\mathrm{R}=$ Market value per share B / Market value per share A $=14 / 1.243=$ 0,0113

Step 6: Calculation of number of shares issued by A

$\mathrm{NI}=$ Value net assets B $/$ Market value per share $\mathrm{A}=28.000 / 1.243=$ $22,5 \approx 23$

Or

$\mathrm{NI}=$ Number of shares $\mathrm{B} *$ Exchange ratio $=2.000 * 0,0113=22,5 \approx 23$

Step 7: Calculation of increase of capital at A

CIA $=$ Number of shares issued $*$ Nominal value of shares A $=23 * 500$ $=11.500$

Step 8: Calculation of merger premium

$\mathrm{PM}=($ Market value per share A - Nominal value of shares $\mathrm{A}) *$ Number of shares issued by $\mathrm{A}=(1.243-500) * 23=17.089$ 


\section{Conclusion}

In the last years in Romania the company's reorganization followed a growing trend and reached high values in terms of number and total value of publicly available private transactions. Romania's path towards a stable economic environment and its desired EU membership contributed to fueling foreign investors' interests in the local market. Among the most active industry sectors from the investor's standpoint were manufacturing, services, financial services and food beverages.

The accession of Romania to the European Union has produced changes in the economic behavior of Romanian entrepreneurs: some of them have chosen to improve the competitiveness of their companies through business partnerships with either financial institutions or strategic investors, some have considered exit options as the most appropriate alternative and others have started to consider acquisitions in neighboring countries.

The data points towards a certain conclusion: as the economy is improving, an increasing number of investors is turning and tuning their focus on Romania. In the last few years many mergers and acquisition were in production, construction and services sectors and the main investors were from Austria, Great Britain, USA etc.

The reorganization is more and more probable in Romanian economy because of multiple changes. The evolution of an economic system supposes reorganization and development from many points of view such as technological, social, and organizational. The essential factor is information, because information has elements about benefits in general, benefits of some activities, market and costs of the future founds.

\section{References}

Horja, I.M.; Vancea, S.; Ignat, A., \& Avram,L. (2010). Operatiunile de restructurare a societăţilor comerciale, Risoprint Publishing House, Cluj Napoca

Reed, F. S. \& Lajoux, R. A. (2007). The Art of M\&A, 4th Ed. McGraw-Hill Professional Publishers, Australia

Bruner, R. (2011). Applied Merger \& Acquisition, ISBN 9781118160824, John Wiley \&Sons

Tiron, T. A. (2005). Business Combination - Mergers and Acquisitions, Accent Publishers, Bucharest

Horja I.M. (2009). Companyes reorganization - an important fact in the current economy, The 6th International Conference on Management of Technological Changes, 3-5 september 2009, Alexandroupolis, Grecia

Sherman, A. (2011). Merger \& Acquisitions from A to Z, ISBN - 13 978-0-8144-13838, Amacom Div Mgmt Assn, New York

Horja I.M.; Vancea, S.; Ignat, A. \& Avram,L. (2009). Merger \& Acquisition: Important Processes in Romania, The 20 th Symposium "Inteligent Manufacturing \& Automation: Focus on Theory, Practice and Education", 25-28, Viena, Austria, ISBN 978-3-901509-70-4, Nov. 2009

Andersen, H; Havila, V \& Nilsson , F. (2013). Merger \& Acquisitions: The Critical Role of Stakeholders, ISBN 978-0-415-53652-3, Routledge, New York 